\title{
Rewriting the Reich: German Women Journalists as Transnational Mediators for Germany's Rehabilitation
}

\author{
Deborah Barton
}

ABstract. This article looks at the transnational impact of two diaries written by the female German journalists Ruth Andreas-Friedrich and Ursula von Kardorff, whose journals shed light on German wartime experiences, resistance activities, and, to a lesser extent, the press. In the postwar years, both journalists sought to influence (West) Germany's relationship with its former enemies, in particular the United States. In their autobiographical writing, they presented both an image of Germany as a victim of Nazism, as well as an early acknowledgment of German crimes. In this way, they achieved a balanced narrative that received a positive reception from American and German audiences. Though the ways in which Friedrich and Kardorff presented aspects of journalism and everyday life in the Third Reich were not unique, their dual identity as women and journalists underlay their ability to act as "legitimate" mediators for Germany's rehabilitation. Western allied occupation authorities and overseas audiences viewed them, in contrast to men, as largely apolitical because they were women, and as objective witnesses because they were journalists. Through their autobiographical writings, both journalists situated themselves among the predominantly male US and German elites devoted to developing amicable relations between the two countries via soft-power diplomacy.

Dieser Aufsatz untersucht die transnationalen Auswirkungen zweier Tagebücher, die der beiden deutschen Journalistinnen Ruth Andreas-Friedrich und Ursula von Kardorff. Die Tagebücher sind auch im Hinblick auf deutsche Kriegserfahrungen, Widerstandsaktivitäten und - in geringerem Ausmaß - die Presse aufschlussreich. Beide Journalistinnen versuchten in den Nachkriegsjahren das westdeutsche Verhältnis zu dessen ehemaligen Feinden, insbesondere den Vereinigten Staaten, zu beeinflussen. In ihren autobiographischen Schriften präsentierten sie ein Bild von Deutschland, das selbst Opfer des Nationalsozialismus war, lieferten aber gleichzeitig ein frühes Eingeständnis der deutschen Verbrechen. Dadurch erreichten beide eine ausgewogene Schilderung, die sowohl vom amerikanischen als auch vom deutschen Publikum positiv aufgenommen wurde. Obwohl das, was Friedrich und Kardorff über die Facetten von Journalismus und Alltag im Dritten Reich zu sagen hatten, nicht einzigartig war, trug ihre doppelte Identität als Frauen und Journalistinnen dazu bei, dass man sie als „legitime“ Mediatoren der Rehabilitation Deutschlands ansah. Die westlichen Besatzungsbehörden und Leser in Übersee betrachteten die beiden im Gegensatz zu Männern als weitgehend apolitisch, weil sie Frauen waren, und als objektive Zeitzeugen, weil sie Journalistinnen waren. Durch ihre autobiographischen Schriften konnten sich die beiden Journalistinnen unter den überwiegend

I would like to thank Andrew I. Port and the two anonymous reviewers for their thoughtful comments. I am also thankful to the Rosa Luxembourg writing group for their insightful feedback and support with this article: Willeke Sandler, Kira Thurman, Julie Ault, Jennifer Lynn, and Lauren Stokes. Thanks as well to Jacob Eder and Keir Waddington for their valuable feedback on early drafts of this article. A fellowship from the Berlin Program for Advanced German and European Studies at the Freie Universität Berlin supported this research. 
männlichen US-amerikanischen und deutschen Eliten etablieren, die mit Hilfe von soft-power Diplomatie freundschaftliche Beziehungen zwischen den beiden Ländern fördern wollten.

$\mathrm{W}$ RITING about the book $A$ Woman in Berlin by Anonymous, a 2005 review in The Telegraph noted, "Her identity is, of course, much less important than her remarkable account of Berlin's final days of war, which will be a gift of the utmost value to historians and students of the period. Her journalistic training is evident from her economy of language and eye for the telling detail, but her extraordinary lack of self-pity is all her own." "The book, based on a wartime diary, describes the last weeks of the war and the beginning of Germany's occupation, as experienced by its author. Another review, this time from The New York Times, declared, "The author is dispassionate and honest about Germany's responsibility for the war that has destroyed it, appalled at news of Nazi atrocities ... She has given us something that transcends shame and fear: the ability to see war as its victims see it." "The reviewer describes the author as a victim, lauds her ability to speak objectively about National Socialist Germany, and credits her with providing a balanced account of German victimization during World War II in light of German crimes. The book was not well received upon its first publication in West Germany in 1954. In the conservative atmosphere of the 1950s, its frank portrayal of rape and socalled sexual fraternization with the occupying forces in exchange for protection was thought to tarnish the honor of German women and depict German men as passive onlookers. ${ }^{3}$ It became an international sensation, however, on its republication in German in 2003 and in English two years later. Since then, $A$ Woman in Berlin has been translated into over twenty languages and is widely available in academic libraries and popular bookstores. ${ }^{4}$ It spent weeks on the bestseller list in Germany and met with critical acclaim in the United States. In 2008, it was made into a film, directed by Max Färberböck. Reviews lauded its balanced look at the collapse of the Third Reich.

The book, released under the pseudonym "Anonymous," was written by a female journalist named Marta Hillers. Throughout the Third Reich, Hillers wrote for a number of publications, including various dailies, illustrated tabloids, women's magazines, and the journal Hilf mit! - a propaganda vehicle produced for German students. ${ }^{5}$ In other words, Hillers's biography suggests that she was not simply the objective witness and victim of Nazism that present-day critics make her out to be. What the book's popularity at the time of its republication does reveal, however, is the endurance of narratives about German victimization and their articulation by women journalists. A Woman in Berlin highlights how the linkages between journalism, gender, and autobiographical writing offered a vehicle for reimagining the Third Reich.

\footnotetext{
${ }^{1}$ Cressida Connelly, "She screamed for help, but her neighbours barricaded the door," Telegraph, July 4, 2005.

2Joseph Kanon, “My City of Ruins,” New York Times, Aug. 14, 2005.

${ }^{3}$ Anonymous, A Woman in Berlin (London: Virago, 2005), xi. German poet and writer Hans Magnus Enzensberger described its initial reception in his foreword to the republished book.

${ }^{4}$ Ibid.

${ }^{5}$ Bundesarchiv Berlin (BArch), RKB76, Marta Hillers, Fragebogen—zur Bearbeitung des Aufnahmeantrages für die Reichsschrifttumskammer, Aug. 1938; Hillers's case report from the US Military Government, Intelligence Section.
} 
A Woman in Berlin is currently the most popular autobiographical work by a woman journalist about her experiences during the Third Reich. This article argues that it is also emblematic of a larger historical trend: from the 1940s onward, women journalists sought not only to refashion their own postwar careers, but also to influence (West) Germany's relationship with its former enemies. They did so largely through their autobiographical writing. Their dual identity as both women and journalists was the primary factor that allowed them to be accepted as legitimate mediators for Germany's rehabilitation. Western allied occupation authorities and overseas audiences viewed them, as women, as largely apolitical, at least in comparison to men; these same groups considered them, as journalists, to be objective witnesses. Women journalists capitalized on this because it seemed to confer greater authenticity on their narratives.

There is a rich vein of literature on the press in twentieth-century Germany, and a wealth of scholarship on the trope of West German victimization that emerged through various media after 1945. Yet, an understanding of the function of women journalists in this context remains incomplete. ${ }^{6}$ In concentrating on two detailed case studies of the careers and autobiographical writings of Ruth Andreas-Friedrich and Ursula von Kardorff, this article bridges these two historiographical areas to recover the roles female journalists played in Germany's rehabilitation. ${ }^{7}$

Ruth Andreas-Friedrich enjoyed a successful career in the 1930s and 1940s, publishing in some of Germany's most popular newspapers and magazines. She wrote on so-called lighter topics, ranging from domesticity to entertainment to interpersonal issues, the very areas that appealed most to men and women alike. ${ }^{8}$ As an opponent of Nazism, Friedrich was distressed about conditions in Germany under the Nazi regime. From the late 1930s onward, she formed, together with a small circle of friends, a resistance group called "Uncle Emil" that provided assistance to Jews and other persecuted Germans. ${ }^{9}$

\footnotetext{
${ }^{6}$ Christina von Hodenberg has identified how a generation of postwar journalists was instrumental for the democratization process in Germany after 1945, but she does not isolate gender as a category of analysis. See Christina von Hodenberg, Konsens und Krise. Eine Geschichte der westdeutschen Medienöffentlichkeit 1945-1973 (Göttingen: Wallstein, 2006). The small body of work that does address women journalists has focused primarily on the limitations women faced within the field; see Carmen Sitter, Die eine Hälfte vergisst man (n) leicht! Zur Situation von Journalistinnen in Deutschland unter besonderer Berücksichtigung des 20. Jahrhunderts (Pfaffenweiler: Centaurus, 1998); Norbert Frei and Johannes Schmitz, Journalismus im Dritten Reich (Munich: C. H. Beck, 1989). For scholarship on the narrative of (West) German victimization and its connection to the Federal Republic's national identity, see Robert Moeller, War Stories: The Search for a Usable Past in the Federal Republic of Germany (Berkeley: University of California Press, 2001).

${ }^{7}$ The biography and writing of Margret Boveri, one of the most prominent female journalists in the Third Reich, resonate with the themes discussed in this article. See Margret Boveri, Verzweigungen: eine Autobiographie, ed. Uwe Johnson (Munich: R. Piper, 1977); see also Michaela Hoenicke Moore, "Heimat und Fremde. Das Verhältis zu Amerika im journalistischen Werk von Margret Boveri und Dolf Sternberger," in Demokratiewunder: Transatlantische Mittler und die kulturelle Öffnung Westdeutschlands 1945-1970, ed. Arnd Bauerkamper, Konrad Jaraush, and Marcus M. Payk (Göttingen: Vandenhoeck \& Ruprecht, 2005), 218-52.

${ }^{8}$ BArch, RKI7, Ruth Andreas-Friedrich, Fragebogen für die Reichsschrifttumskammer, 1936 and 1938 ; Karl Christian Führer, "Pleasure, Practicality, and Propaganda: Popular Magazines in Nazi Germany, 1933-1939," in Pleasure and Power in Nazi Germany, ed. Pamela E. Swett, Corey Ross, and Fabrice d'Almeida (Houndmills: Palgrave Macmillan, 2011), 134.

${ }^{9}$ She was well positioned to discuss Jewish suffering: Yad Vashem honored her as a "Righteous Among the Nations" in 2002 for her assistance to Jewish Germans. See http://www.yadvashem.org/yv/en/righteous/statistics/germany.pdf.
} 
Ursula von Kardorff's relationship with Nazism was more entangled. Her father was an outspoken critic of the party, whereas her mother supported the regime prior to and throughout the war; her brother Klaus was a member of the Sturmabteilung (SA). At the same time, the family was concerned about the treatment of its Jewish friends. ${ }^{10}$ As a member of the Prussian aristocracy, Kardorff was also socially acquainted with the small circle of army officers that planned the assassination attempt of July 20, 1944, on Adolf Hitler. By her own description, she played a minor role in its aftermath by delivering a message to a conspirator's wife and was questioned more than once by the Gestapo. Although Kardorff viewed herself as an anti-Nazi, she was also a German nationalist. She did not consider the war a "Nazi" war and did not particularly want to see Germany defeated. ${ }^{11}$ Kardorff began her career in 1937 at the Nazi party paper, Der Angriff. In 1938, she secured a position at the conservative Deutsche Allgemeine Zeitung, where she worked in the features section until she fled Berlin in February 1945.

Friedrich and Kardorff represent journalists who came from different professional backgrounds, had different relationships to Nazism, and took different paths from dictatorship to democracy. Yet, in distinct ways and at specific points, through a process of distortion, repression, and remembrance, they provided an account of Germany as both victim and perpetrator-one that critics hailed as balanced and that achieved a lasting resonance in discussions of Germany's past. Existing scholarship has used the writing of these women to think about the German war experience on the home front, German opposition activities, and, to a lesser extent, the functioning of the Nazi press. This article shifts the focus to examine how Friedrich and Kardorff's gender and status as professional journalists were important components of the way in which they successfully marketed a distorted version of Germany during the Third Reich to German and transnational audiences after 1945. Given that both women lived in the US occupation zone, wrote for US licensed papers, and were subject to US press policy, the article primarily focuses on American reception of their work. First, it discusses the entanglement of gender and journalism. It then briefly highlights the role of women in the press in Nazi and postwar Germany. Finally, it turns to Friedrich and Kardorff's writings and their reception.

A journalist's importance in the public sphere means that such individuals command a certain level of authority: they have the professional status, skills, and contacts to affect public opinion, while reaching domestic and overseas audiences. This influence was especially of interest in the postwar period because the US occupation force ascribed much importance to the media's role in reeducating the German population in the ways of democracy. The 1947 Fair Practice Guide for German Journalists, which expressed such views, was prepared by the US Office of the Military Government, Information Control Division (OMGUS, ICD), as a guide to encourage a deeper understanding of the principles underlying democratic journalism: "We believe that the success of democratic government depends upon sound public opinion, and that the newspaper should aid in creating and maintaining sound public opinion ..."12 US authorities considered not only the press as a whole, but also

\footnotetext{
${ }^{10}$ Institut für Zeitgeschichte (IfZ), Munich, ED ED348/2, undated letter from von Kardorff's mother to H., 1934.

${ }^{11}$ Nicholas Stargardt, The German War: A Nation Under Arms, 1939-1945 (New York: Basic Books, 2015), 266, 416.

${ }^{12}$ The Fair Practice Guide for German Journalists: Wegweiser zum guten Journalismus (Munich: Office of Military Government for Bavaria [Information Control Division/Press Control Branch], 1947), 10.
} 
individual journalists as important shapers of public opinion, and they placed emphasis on a journalist's obligation to present information in an unbiased fashion. ${ }^{13}$ Friedrich and Kardorff's work needs to be viewed in this context. Their identity as journalists afford their narratives legitimacy, but they also had the skills to write in a seemingly unbiased or balanced fashion.

Gender also informed the positive reception of Friedrich and Kardorff's work and gave them a greater ability to reflect German victimhood than men had. The fact that women journalists worked largely outside the formal structures of power, but within a public institution, underlay their ability to wield influence. The ways in which Friedrich, Kardorff, and other women journalists presented aspects of journalism and everyday life in the Third Reich were not unique. However, unlike most German women, these journalists enjoyed a public role, had domestic and foreign contacts in the press, and could expect their work to be published and reviewed. Moreover, in contrast to their male colleagues, these women could allege that their work had not been political and/or that they had been victims during the Third Reich because of their gender. For decades after the war, two primary views prevailed concerning women and their connection to Nazism: women were either largely apolitical and therefore bore little responsibility for National Socialist crimes, or they were victims of Hitler's misogynist regime. ${ }^{14}$ Either status gave women an advantage when it came to representing and rebuilding a decent Germany-one that men, for the most part, did not enjoy. Some male journalists also wrote postwar memoirs that addressed their careers during the Third Reich. But these works typically did not have the same traction or popularity as those of women journalists. A case in point: in their pioneering work, Journalismus im Dritten Reich, Norbert Frei and Johannas Schmitz relied on eleven memoirs, four of them from women journalists, including Friedrich and Kardorff. The seven men's memoirs used for the study were published only in German from the late 1960s to the early 1980s, with most appearing in the 1970s. Unlike Friedrich and Kardorff's memoirs, they have not been translated or reissued.

\section{Women in the National Socialist and Postwar Press}

Nazi ideology loudly proclaimed that women belonged only in the private sphere. Reality was different from rhetoric in Nazi Germany, where the economic situation required many women to work outside the home, most often in menial and low-paying positions. Likewise, the regime relegated women journalists to a seemingly subordinate status within the field. From 1933 to 1945, women never comprised more than 10 percent of accredited journalists. ${ }^{15}$ At the same time, the regime stressed that women were to be an important part of the esteemed institution of the press. Indeed, the number of women in the field increased in the Third Reich. In a 1936 study, Adolf Dresler, a respected lecturer in journalism at the University of Munich, found that, whereas only 222 women had been members of

\footnotetext{
${ }^{13}$ Ibid.

${ }^{14}$ See Atina Grossmann, "Feminist Debates about Women and National Socialism," Gender \& History 3 , no. 3 (1991): 350-58; Claudia Koonz, Mothers in the Fatherland: Women, the Family, and Nazi Politics (New York: St. Martin's Press, 1987); Gisela Bock, Zwangssterilisation im Nationalsozialismus: Studien zur Rassenpolitik und Frauenpolitik (Opladen: Westdeutscher Verlag, 1986).

${ }^{15}$ Sitter, Die eine Hälfte, 21.
} 
the German Press Association in 1932, this number had grown to 687 by 1935, a 43 percent increase. ${ }^{16}$

In a speech to a gathering of female journalists in March 1936, the head of the Reichsverband der deutschen Presse (German Press Association, RDP), Wilhelm Weiss, addressed the Nazis' view of the professional landscape for women. Women journalists, he emphasized, were to be a vital part of the press: "If the journalism profession is to acquire the necessary esteem in the National Socialist state, it must stand in unity. Women who are a part of the profession will render great service ... to the German press itself." 17 Weiss maintained that the role of a female journalist would be to write about topics and in rubrics that would primarily interest women. The latter included the women's supplements, features, "soft" news sections such as travel, and local events.

Nazi press authorities depicted these areas as apolitical, but they were, in many ways, more important to the regime and to the German public as a whole than the "hard" news sections, which primarily remained the domain of male journalists. By focusing on human-interest stories and areas dedicated to seemingly private concerns, women journalists offered Germans a much-desired break from overt ideological indoctrination and provided them with some sense of normality under the Nazi regime. In this way, women journalists helped the regime achieve broad acceptance in the eyes of the population. They helped create a positive image of Nazi Germany that acted as a counterbalance to the repression and terror propagated by the regime. ${ }^{18}$ Only a few women managed to forge careers beyond these areas as political reporters or foreign correspondents. Women journalists were thus both insiders and outsiders in the Nazi press. Their insider status gave them the professional skills and legitimacy to write after the war about their experiences inside the Nazi press, as well as about their own - and the population's-experiences during the Third Reich. Their outsider status, by contrast, distanced them from overtly Nazified news and propaganda. ${ }^{19}$

In the immediate postwar years, the professional landscape for women journalists appeared promising as a result. The young radio journalist Lore Walb later recalled the opportunities open to women after 1945: "At that time women journalists stood under a lucky star. Journalists were rare and the Americans ... implemented a very women-friendly personnel policy. Never again did women have ... such chances as the ones [they] received in the radio and press in the American occupation zone shortly after the war." 20 In the initial phase of denazification, US occupation authorities endeavored to staff newspapers with politically uncompromised journalists. To that end, Germans and US authorities adhered to the Nazi regime's distinction between political and apolitical material. The accepted notion that most women journalists had operated primarily in the apolitical realm-or at least in less overtly political areas during the Third Reich-meant that women could function more readily in the field in the first postwar years than they could by the close of the decade, when the Allies abandoned their denazification efforts. ${ }^{21}$

\footnotetext{
${ }^{16}$ Adolf Dresler, Die Frau im Journalismus (Munich: Knorr \& Hirth, 1936), 11.

${ }^{17}$ Wilhelm Weiss, "Die Frau im Schriftleiter Beruf," Deutsche Presse, March 7, 1936.

${ }^{18}$ Corey Ross, Media and the Making of Modern Germany: Mass Communications, Society, and Politics from the Empire to the Third Reich (Oxford: Oxford University Press, 2008), 375.

${ }^{19}$ See Deborah Barton, "Writing for Dictatorship, Refashioning for Democracy," PhD diss., University of Toronto, Toronto, 2015.

${ }^{20}$ As quoted in Sitter, Die eine Hälfte, 218.

${ }^{21}$ Ibid., 264.
} 
In the female-dominated landscape of the postwar period, the ICD identified women as an important symbol and target group in their task to rebuild Germany, and women journalists were seen as a means to reach this group. The ICD particularly encouraged the creation of publications targeted toward women. ${ }^{22}$ In July 1945, journalist Frances McFadden was working on the draft of a women's magazine titled Wir Frauen, which was to be published in the US occupation zone. For the first issue, McFadden wanted to include a survey of German women's responses to questions related to the theme of peace, e.g., "What can German women do to help Germany win back the respect of other nations?"23 Such articles suggested that German women would make an important contribution to the social and moral rebuilding of their country. When the Women's Affairs Branch of OMGUS was established in 1948, its mission was to "further the attempts" of the German voluntary associations of women "to exercise a constructive role in the reestablishment of democratic procedures in community life." 24

Despite such early efforts to give women a more prominent place in the public realm, society began to drift back to a more traditional gender order after the founding of the Federal Republic in 1949. Women began to suffer renewed discrimination and restrictions in the labor market, including in the press. ${ }^{25}$ As an increasing number of male journalists returned to the field, women were soon relegated to the periphery of the profession and largely restricted to the women's pages or to themes oriented toward women. ${ }^{26}$ For instance, in an effort to create a democratic press in postwar Germany and to foster improved relations between the two countries, the United States developed formal exchange programs for German journalists to learn from colleagues in America. These programs were initially and primarily for men, however. ${ }^{27}$

Even though men were prominent in such exchanges, women journalists such as Friedrich and Kardorff nevertheless obtained a greater voice by writing about their personal experiences during the Third Reich. More to the point, it was through such autobiographical work that they endeavored to assert their influence on postwar discourses about Germany's Nazi past, largely by presenting an image that achieved the sort of balance its former enemy was looking for from journalists, and thus to rehabilitate Germany in the eyes of the outside world. In this way, they situated themselves among the predominantly male US and German elites devoted to developing amicable relations between the two countries via soft-power diplomacy. ${ }^{28}$

\footnotetext{
${ }^{22}$ Erwin J. Warkentin, "History of the Information Control Division, OMGUS, 1944-1946," Memorial University of Newfoundland (http://www.erwinslist.com/index-en.html).

${ }^{23}$ IfZ, 5/266-1/1, memorandum from Frances McFadden to Bob Hatch, July 26, 1945.

${ }^{24}$ As quoted in Helen Laville, Cold War Women: The International Activities of American Women's Organisations (Manchester: Manchester University Press, 2002), 76.

${ }^{25}$ Elizabeth Heineman, “The Hour of the Woman: Memories of Germany's 'Crisis Years' and West German National Identity,” American Historical Review 101, no. 2 (1996): 354-96.

${ }^{26}$ Sitter, Die eine Hälfte, 251.

${ }^{27}$ IfZ 5/236-2-10, OMGUS, itinerary of German journalists after Columbia seminars, n.d.

${ }^{28}$ Volker Berghahn, America and the Intellectual Cold Wars in Europe: Shepard Stone between Philanthropy, Academy, and Diplomacy (Princeton, NJ: Princeton University Press, 2001).
} 


\section{Ruth Andreas-Friedrich (1901-1977)}

In November 1945, the ICD cleared Ruth Andreas-Friedrich as "nicht betroffen" (untouched) by Nazism and issued her a license to publish, together with two male colleagues, a women's magazine titled Sie. Consistent with the Nazis' narrative about the "soft" nature of female journalism, the office's report stated that, during her career under the Third Reich, Friedrich had written only on themes that were "of an unpolitical nature." ${ }^{29}$ During the war, she wrote for Die Junge Dame, a magazine aimed at young, single women, that merged in 1943 with two other magazines to form a new publication titled Kamerad Frau, with Friedrich as editor. In accordance with National Socialist press directives in 1943 that began to call for increased antisemitic propaganda in German publications, it was during Friedrich's tenure as editor that the new magazine produced its most inflammatory articles against Jews. ${ }^{30}$ ICD officials did not refer to her involvement with Kamerad Frau after the war because it considered her to be precisely the type of figure they desired as a conduit to the German population. US assumptions about women and the nature of women's journalism during the Third Reich, as well as Friedrich's wartime involvement in the resistance group Uncle Emil, can also explain this silence. Despite serving the regime in a journalistic capacity, Friedrich loathed Nazism and privately fought to resist it - a view that gave her autobiographical writing added authority and veracity for non-German audiences.

In the fall of 1946, Friedrich stepped back from her position as publisher at Sie because of conflict with her male partners. Friedrich had desired a woman's magazine that discussed political issues and that endeavored to inculcate more democratic values in German society; her male colleagues envisioned a publication that primarily addressed cosmetics, fashion, and domestic topics - notions that were in keeping with traditional views about the "appropriate" role for women journalists during, and for decades after, the Third Reich. ${ }^{31}$ Despite the challenges she faced in her journalistic career, Friedrich became an important and well-known voice in postwar discourses about Germany's Nazi past thanks to the English-language publication of her book, Berlin Underground, 1938-1945. ${ }^{32}$

Friedrich wrote Berlin Underground in the hope that it would help alter foreign views of Germans. Her intention was to draw a distinction between the Nazi regime and the country as a whole, and to highlight the idea that the Nazis had victimized what she considered to be the "good" Germany. Friedrich used her transatlantic connections to get across her message about Germany to a larger audience. In fact, she deliberately sought to publish abroad before doing so in Germany. ${ }^{33}$ In late 1945, she sent her manuscript, based on her wartime diary, through an American press officer to a friend in the United States, who, in turn, forwarded it to the Jewish-German émigré author Carl Zuckmayer, who then recommended the

\footnotetext{
${ }^{29}$ BArch RK I7, Michael Jobbelson, US Civ. Chief of Research Section, report, Office of Military Government, Information Control Branch, US Army, June 2, 1947.

${ }^{30}$ Kamerad Frau, Jan. 1, 1944. In February 1944, Kamerad Frau introduced the series "Sie sind schuld daran," which aimed to show how great thinkers identified the ways in which the "actions of the Jews" had sought to crush the German people and culture throughout history.

${ }^{31}$ Karin Friedrich, Zeitfunken. Biographie einer Familie (Munich: C. H. Beck, 2000), 274-75.

${ }^{32}$ Ruth Andreas-Friedrich, Berlin Underground, 1938-1945, trans. Barrow Mussey (New York: Henry Holt \& Co., 1947).

${ }^{33}$ See Jörg Drews's afterward in Ruth Andreas-Friedrich, Der Schattenmann. Tagebuchaufzeichnungen 1938-1948 (Berlin: Suhrkamp, 2000), 570.
} 
manuscript to US publisher Henry Holt. ${ }^{34}$ When Berlin Underground appeared in the United States in early 1947, it was the first postwar book that Holt published by a German who had not emigrated from Nazi Germany.

According to Friedrich, it was in the summer of 1938 that she decided she would become a witness to this good Germany. While on a trip to Sweden, Friedrich had tried to speak with Rosalind von Ossietzky, the daughter of the deceased German pacifist and publisher, Carl von Ossietzky. ${ }^{35}$ But after learning that Friedrich did not intend to emigrate from Germany, Rosalind refused to speak with her. It was in that moment, Friedrich recalled, that she decided to keep a diary. She believed that, at some point, Germans would face the difficult task of having to "prove to those outside that not every German who stayed in Germany was a Nazi." 36 Friedrich viewed her diary as a testimony that would later help facilitate understanding between Germans and the international community.

In the aftermath of the war, Friedrich wrote of her intention to rehabilitate the reputation of those who, like her, had remained in Germany throughout the Third Reich. On August 23, 1945, she noted, "Yesterday two Americans invited us to be their guests. We are pleased at every opportunity to convince the victors that German people aren't necessarily different from them." ${ }^{37}$ For Friedrich, what was crucial for Germany was "to be understood the way we really are" - not as a country comprised of just Nazis and antisemites: "We would like to get this message to all ears, all minds and hearts ... For Heaven's sake, what wouldn't we do in our passionate desire to clear up the mess." 38 To achieve this, Friedrich, like the authors of other postwar accounts, placed most of the blame for Nazism and its crimes on only a handful of perpetrators, explaining in the foreword:

Germany today is the bad child of the world. The tendency is to identify the whole people with the outrages of its leaders. Yet thousands upon thousands had nothing whatever to do with those outrages. On the contrary, year in and year out they risked life and liberty-with no help from foreign nations ...-to serve humanity wherever they could ... May [this book] go out into the world to testify that there were human beings living even under Hitler in Germany-human beings who do not deserve to be despised along with their whole nation, because of an irresponsible government. If that be accomplished, these notes will have fulfilled their purpose by helping in some small measure to raise the German people a hairsbreadth from its present low degree in the eyes of the world. ${ }^{39}$

One of the key ways in which Friedrich sought to achieve her goal of presenting this good Germany to foreign audiences was by documenting the escalating persecution of Jews, as well as the actions that she and others took to assist Jewish friends and acquaintances in danger. In an entry dated September 19, 1941, Friedrich described how Jews were now forced to wear the yellow Star of David. She also documented the regime's appropriation of Jewish apartments and what she described as "forced evacuations with destination

\footnotetext{
${ }^{34}$ Friedrich, Zeitfunken, 268, 276.

${ }^{35}$ Ossietzky, the publisher of the leftist paper Die Weltbühne, was arrested by the National Socialists in February 1933, and sent to Esterwegen concentration camp. He was awarded the Nobel Peace Prize two years later, but the Nazi regime refused to release him from the camp. He died in 1936. See Werner Boldt, Carl von Ossietzky: Vorkämpfer der Demokratie (Hannover: Ossietzky, 2013).

${ }^{36}$ Andreas-Friedrich, Der Schattenmann, 568-69.

${ }^{37}$ Ruth Andreas-Friedrich, Battleground Berlin: Diaries 1945-1948, trans. Anna Boerresen (New York: Paragon, 1962), 86.

${ }^{38}$ Ibid.

${ }^{39}$ Andreas-Friedrich, Berlin Underground, xiii-xiv.
} 
unknown. To Jewish concentration camps in Poland, some predict. To certain death say others." ${ }^{40}$ In this way, Berlin Underground not only provided, in precise and emotive ways, an early postwar testimony about Jewish oppression, but also acknowledged that some Germans did indeed know what had been transpiring. ${ }^{41}$

At the same time, Friedrich's text distanced the journalistic profession and the country as a whole from the stigma of Nazism by attributing responsibility for the escalating crimes against Jewish Germans to only a handful of Nazis. Several passages depict fellow journalists, and indeed most Germans, either as mortified by the regime's actions or as heroically assisting Jews. By Friedrich's account, the morning after Kristallnacht on November 9, 1938, her journalist colleagues discussed the pogrom and the deep shame they felt, with her editor supposedly lamenting: "My dear girl, I shan't live through this. We ought to be so ashamed we could sink into the floor. Synagogues - houses of God-temples of the Lord simply soaked down with gasoline." 42 Friedrich wrote that her publisher had joined the NSDAP only to have access to party bigwigs because they might prove useful at some stage. ${ }^{43}$ In postwar Germany, Friedrich's insinuation that even Nazis were not "real" Nazis was useful to journalists and the population at large. Coming from a figure like Friedrich, who was respected by US occupation authorities, such a suggestion helped legitimize the alibis of others who claimed that they had only joined the party for noble or selfless reasons. ${ }^{44}$

In making these distinctions, one of Friedrich's objectives in publishing her manuscript was to highlight what she depicted as resistance activities by ordinary Germans:

For twelve and a half years the German people lived inside prison walls. What actually took place inside those walls almost never reached the public ear. The Nazis had many adversaries in Germany ... They knew of all the atrocities that took place, though only through rumor. And preciously because they knew and foresaw all this, they felt it their duty to use their energies on the spot. Then at least not all intended outrages might be carried out ... Countless 'wanted' persons who went underground could never have stuck it out to the end but for the help of strangers. ${ }^{45}$

In Friedrich's narrative, much of the non-Jewish German population strove to help Jews during the war. In June 1942, nine months after the deportations to the East had begun, she noted that many Germans were helping to feed Jews: "A great many people with guilty looks are lugging shopping nets full of vegetables through the streets of Berlin." 46 As the end of the war loomed, she claimed that "we who are in our eleventh year under Hitler's dominion have little cause to boast. But, if ever anyone risked his life for his

\footnotetext{
${ }^{40}$ Ibid., 70.

${ }^{41}$ See Stargardt, German War.

${ }^{42}$ Andreas-Friedrich, Berlin Underground, 19.

${ }^{43}$ Ibid., 191.

${ }^{44}$ See, e.g., Theodor Schieder's five volumes on German expellees: Documents on the Expulsion of the German Population from the Territories East of the Oder-Neisse Line (Bonn: Federal Ministry for Expellees, Refugees, and War Victims, 1958-1961). Schieder's work focused on the violence inherent in the expulsion of millions of Germans from Eastern Europe, but it paid scant attention to German crimes. As Robert Moeller has written, the work amounted to a "scholarly seal of approval" for the narrative about German victimization. See Moeller, War Stories, 84. For more on the German expulsions, see R. M. Douglas, Orderly and Human: The Expulsion of the Germans after the Second World War (New Haven, CT: Yale University Press, 2012).

${ }^{45}$ Andreas-Friedrich, Berlin Underground, xiii.

${ }^{46}$ Ibid., 78.
} 
Jewish brothers, it has been the German Aryans-hundreds, thousands, tens of thousands, risking their necks every day and every hour ... for a few wretched bread stamps, a lodging for a night or two ... scraped together out of their own need, fought for among bombs, forced labor, failing communications, and personal hardship ..."47 Friedrich and her small circle certainly took risks to help Jewish friends and even strangers during the Third Reich. Yet, her book attempted to construct for US and German readers a myth of widespread German resistance to Jewish persecution. As later accounts would show, this depiction seriously distorted reality: most of the German population was, at best, apathetic to Jewish suffering. ${ }^{48}$

Friedrich also contributed to the popular idea that Hitler had led unwilling and victimized Germans to the abyss. In doing so, she downplayed the support the Nazis had enjoyed from much of the German population. In Friedrich's view, Germans had twice been victims: first of a chaotic interwar period, and then of the Nazi regime. In Berlin Underground, she presented the view that her fellow citizens "gave the devil an inch back in 1933" because they had "feared for their livelihood, for the life and welfare of their wives and children. Because they were afraid of hunger and unemployment, of denunciations, the Gestapo, the scaffold." ${ }^{49}$ Friedrich clearly presented a view of Germans as victims, but she also spoke about German responsibility for Nazism. In an entry from February 1943, for instance, she discussed the massive roundup of the remaining Jews in Berlin that had recently taken place, describing an English bombing raid as retribution for "the monstrous deed." At the same time, she criticized the German population's focus on its own suffering, as well as its failure to see a link between its support of the regime and its present circumstances: "They can't grasp it that they - they in particular - should have been the ones to suffer so. From cause to effect is a long road. Very few people know enough to follow it." 50 As reviews of the book suggested, Friedrich's description of such events presented a seemingly objective balance that lent her work credibility, in the eyes of US occupation authorities and audiences, that went beyond her status as a woman and as a member of a resistance group.

In the mid- to late 1940s the press was not (yet) silent about German atrocities committed during the war. German newspapers covered the Nuremberg trials more intensively than later war crimes proceedings. (Whether they would have done so without Allied control of the press is difficult to say.) In their reporting of the trials, journalists placed responsibility for German crimes on a small gang of Nazi criminals, which gave ordinary Germans an opportunity to absolve themselves of guilt and responsibility. ${ }^{51}$ In addition, the trials did not focus on the genocide of the Jews as a specific and separate aspect of Nazi atrocities. Friedrich's narrative not only fit into but also expanded this type of media discourse.

\footnotetext{
${ }^{47}$ Ibid., 118.

${ }^{48}$ Richard Lutjens, "Vom Untertauchen: 'U-Boote' and der Berliner Alltag 1941-1945," in Alltag im Holocaust, Jüdisches Leben im Großdeutschen Reich 1941-1945, ed. Andrea Löw, Doris L. Bergen, and Anna Hájková (Munich: Oldenburg, 2013), 57. See also Ian Kershaw, Popular Opinion and Political Dissent in the Third Reich: Bavaria 1933-1945 (Oxford: Oxford University Press, 2002), 224-77.

${ }^{49}$ Andreas-Friedrich, Berlin Underground, 134. See also Robert Gellately, Backing Hitler: Consent and Coercion in Nazi Germany (Oxford: Oxford University Press, 2001).

${ }^{50}$ Andreas-Friedrich, Berlin Underground, 91.

${ }^{51}$ Host Pöttker, Abgewehrte Vergangenheit. Beiträge zur deutschen Erinnerung an den Nationalsozialismus (Cologne: Herbet von Halem, 2005), 120-21.
} 
The fact that she addressed Germany as both victim and perpetrator helped make her book acceptable to US press authorities in Germany and to US audiences. On the one hand, the former hoped to curb the publication of material that focused too heavily on German suffering. As the Fair Practice Guide for German Journalists noted:

There are numerous indications that Germany's difficulties are appreciated— but editorial writers in particular should remember the theme of "poor suffering Germany" was so overworked by Nationalist and Nazi propaganda before and during the Third Reich, that it will take more than a litany of wails to get Germany a hearing on this topic. A better solution is good, honest journalism, free of sarcasm, nagging, cajolery, yelled threats and whining. Understatement is more effective than overstatement. ${ }^{52}$

On the other hand, the ICD did take steps to ensure that the material that was published was well received by Germans. ${ }^{53}$ Friedrich's narrative fulfilled both criteria because she consciously wrote for what she hoped would be her foreign, and later domestic, audiences.

That said, little is known about the editing process of Friedrich's diary before publication, including the degree of input editors at Henry Holt may have had on the finished text. ${ }^{54}$ Any editing was likely to have been minimal, however, given that it was translated and published within just over a year of Friedrich's submission of the manuscript. Published first in the United States and shortly afterward in Berlin, Friedrich's book struck a balance between the presentation of German crimes and the suffering of ordinary Germans in a manner that was both acceptable to the United States and appealing to Germans. This positive reception, as well as the endurance of her narrative, are evident from the fact that Berlin Underground was republished many times in English and German, most recently in the year 2000. In addition, excerpts appeared in other articles about the German war experience, including in a popular series that appeared in Die Welt in 1962, "Chronical of Our Most Difficult Days." 55

In his introduction to Friedrich's book, US journalist and war correspondent Joel Sayre, who covered the final days of the war in Germany for the New Yorker, praised her work, highlighting how Germans like Friedrich could help build a bridge of reconciliation between the two wartime foes: "We, the people of the United States, have undertaken to educate the Germans under our control in the best ways of our democracy. If we are ever to get anywhere with such a staggering project, it is with Germans like Ruth and her friends that we must work." 56 Many reviews, ranging from ones in The New York Times to small academic journals, presented US audiences with similarly positive assessments of her work. They lauded Friedrich's presentation of a good Germany, as well as the supposed authenticity of her words, with one review in Social Forces celebrating Friedrich's book as

an extremely interesting, excitingly written account of the activities of one of the many small groups of anti-Nazis that operated in Berlin during the years of 1938 to $1945 \ldots$ If ever the history of the German resistance groups should be written, Mrs. Friedrich's book will be a

${ }^{52}$ Fair Practice Guide, 6.

${ }^{53}$ IfZ 5/265-1/11, report on German prisoner reactions to the magazine HEUTE, n.d. For American efforts to reshape the German press, see Jessica Gienow-Hecht, Transmission Impossible: American Journalism as Cultural Diplomacy in Postwar Germany, 1945-1955 (Baton Rouge: Louisiana State University Press, 1999).

${ }^{54}$ Friedrich claimed that she had "deliberately refrained from any subsequent emendations." See the foreword to Andreas-Friedrich, Berlin Underground.

${ }^{55}$ The German edition was titled Der Schattenmann. Tagebuchaufzeichnungen 1938-1945. It was republished several times in the 1970s, 1980s, and 1990s. See IfZ, ED348/9, letter from Max Tau, Aug. 9, 1962.

${ }^{56}$ Andreas-Friedrich, Berlin Underground, xii. 
valuable source ... Central facts are pointed out very convincingly: first, that more "Aryans" risked their lives to give aid to Jewish people than is generally assumed... ${ }^{57}$

Another review opened with the following claim: "During the war the American public became acquainted with the black record of Germany. It is natural that a reaction to the total condemnation should set in now with the first publications on what could be called the white record of a good many Germans during the Hitler period." 58 Some reviews made their own transatlantic connections in celebrating her work. For instance, reviews of a study on the German resistance, written by the former Office of Strategic Services (OSS) chief of station in Bern and future CIA director Allen Dulles, included references to Friedrich's book. ${ }^{59}$ The New York Times also compared her book favorably with that of Dulles, and such connections only reinforced her status as a trusted and authentic voice. ${ }^{60}$ Friedrich's writing skills, and her status as a resister and woman journalist who wrote on socalled apolitical issues, ensured that — as German émigré historian Hans Rothels noted in his 1948 book, The German Opposition, An Appraisal - her work had "all the ring of truth."61

Friedrich's views may have been particularly well received in the United States because of the context in which her work appeared. As the Cold War developed, the Soviet Union quickly replaced Germany as the West's enemy - a shift that provided fertile ground for a narrative depicting German victimization and heroism. In a rapid readjustment of its perspective on Nazi Germany, US occupation forces and the American public quickly "feminized" the defeated country and cast itself in the role of the "masculine" provider and protector. ${ }^{62}$ The fact that American views on Nazi Germany prior to and even throughout the war were mixed - and, in fact, often generous — allowed for this quick realignment, as well as the enthusiastic reception of Friedrich's book. ${ }^{63}$ Around the same time that Berlin Underground first appeared in the United States and Germany, US President Harry Truman announced the eponymous doctrine designed to fight Soviet expansionism. In 1947, the United States also began a massive aid program under the Marshall Plan to assist European economic recovery and reduce the appeal of communism. The Berlin blockade and airlift, an important event in establishing Germany as a victim in the eyes of the West, began in June 1948, and Friedrich's book was published in England that same year. ${ }^{64}$ The book's early publication and its continuing popularity have made Friedrich one of the most respected "authorities" on life in Germany during the Third Reich. Yet, her acknowledgment of German crimes, together with her depiction-however distorted-of the

\footnotetext{
${ }^{57}$ Rudolf Heberle, “Berlin Underground, 1938-1945," Social Forces 26, no. 1 (1947): 109.

${ }^{58}$ Allen Welsh, "Berlin Underground," Survey Graphic 36 (1947): 552.

${ }^{59}$ Emile de Groot, "Germany's Underground," International Affairs 24, no. 1.(1948): 127-28. Allan Dulles served as the OSS Berlin station chief for six months after the war, and became the longest serving director of the CIA.

${ }^{60}$ Richard Plant, “A Gallant Anti-Hitler Diary, Berlin Underground,” New York Times, June 1, 1947.

${ }^{61}$ Hans Rothfels, The German Opposition to Hitler, An Appraisal (Hinsdale: H. Regnery, 1948), 33.

${ }^{62}$ See Petra Goedde, GIs and Germans: Culture, Gender, and Foreign Relations, 1945-1949 (New Haven, CT: Yale University Press, 2003); see also Maria Höhn, GIs and Fräuleins: The German-American Encounter in 1950s West Germany (Chapel Hill: University of North Carolina Press, 2002).

${ }^{63}$ See Michaela Hoenicke Moore, Know your Enemy: The American Debate on Nazism, 1933-1945 (Cambridge: Cambridge University Press, 2010).

${ }^{64}$ Ruth Andreas-Friedrich, Berlin Underground (London: Latimer House, 1948). See The Big Lift, dir. George Seaton, April 1950. The film depicts the narrative of German victimization and US receptiveness to that idea.
} 
German population's sympathy toward German Jews, created an image of wartime Germany that suited both American and German audiences.

\section{Ursula von Kardorff (1911-1988)}

In the immediate postwar years, Ursula von Kardorff similarly sought to improve Germany's image abroad and distance herself from any connection with Nazi propaganda related to her journalistic activities during the Third Reich. She did so through press articles and an autobiographical narrative that emphasized Germany's heroism and suffering. Throughout the war, Kardorff had worked in features, writing about women's issues, including the bravery and resilience of German women. After the war, she worked as a freelance journalist for several large dailies, including the Süddeutsche Zeitung and the Frankfurter Allgemeine Zeitung. Kardorff wrote about many topics, from the hardships of expellees, widows, and prisoners-of-war, to trends in fashion and decorating. ${ }^{65}$ Whereas during the Third Reich some of her articles had depicted Nazism as a vehicle for female empowerment, after the war she emphasized women's victimization at the hands of the regime and the war it had waged. ${ }^{66}$

In 1950, she accepted a permanent position at the Süddeutsche Zeitung, where she continued to write about culture, travel, and women's issues, as well as about the German war and postwar experience. The Süddeutsche was the first US licensed paper in Bavaria and it soon became a well-respected national publication. ${ }^{67}$ The ICD and the paper's editor, Edmund Goldschagg, viewed the Süddeutsche as an instrument for guiding Germans toward a democratic worldview. Kardorff also wished to see Germany evolve into a postwar democracy, yet depicted herself as apolitical. In personal and professional correspondence, she discussed her distaste for what she described as "political women." 68 In the late 1940s and 1950s, Kardorff worked directly for the culture editor, Franz Joseph Schöningh, with whom she shared the view that the German population had suffered greatly under Hitler. In the paper's first issue on October 6, 1945, Schöningh wrote that the Germans had simply been "seduced by Hitler" and that the population had "lived in hell" under the National Socialists. ${ }^{69}$ On September 2, 1948, he wrote that the Germans had desired peace but had been lied to endlessly and eventually "led to the slaughter" by the Nazi regime. ${ }^{70}$

The nature of Kardorff's journalism in the mid-1940s and 1950s, and her claim to be apolitical, corresponded to Schöningh's perspective on the past, as well as to his view of women journalists. In 1946, he assigned Kardorff to cover the Nuremberg trials because he wanted a female correspondent who might offer a different perspective from that of male journalists.

\footnotetext{
${ }^{65}$ See, e.g., "Angst vor den Möbeln unserer Zeit," Süddeutsche Zeitung, Jan. 13, 1953; IfZ Munich, ED348/5, Kardorff Nachlass. She also wrote the popular column "Durch meine Brille" for the Münchner Abendzeitung.

${ }^{66}$ See, e.g., Ursula von Kardorff, "Die Frau von dreißig Jahren," Deutsche Allgemeine Zeitung [Oct. 1944]; idem, "Frauen und nicht Soldat: Die Luftwaffe stellt Flakwaffenhelferinnen ein," Deutsche Allgemeine Zeitung, June 6, 1944.

${ }^{67}$ Knud von Harbou, Als Deutschland seine Seele retten wollte: Die Süddeutsche Zeitung in den Gründerjahren nach 1945 (Munich: DTV, 2015).

${ }^{68}$ See, e.g., IfZ ED348/5, letter from Kardorff to Krellmann, March 9 [1947].

${ }^{69}$ Franz Joseph Schöningh, "Lohnt es sich noch zu leben?,” Süddeutsche Zeitung, Oct. 6, 1945.

${ }^{70}$ Schöningh, as quoted in Knud von Harbou, Wege und Abwege. Franz Josef Schöningh, der Mitbegründer der Süddeutschen Zeitung. Eine Biografie (Munich: Allitera, 2013), 234.
} 
No background in politics was required, he emphasized. ${ }^{71}$ Kardorff's writing on the trials reveals the complexity of her thinking. She was appalled at the horrors committed by and in the name of Germans, and confronted those atrocities in her articles. Yet, much of her work placed responsibility for German crimes in the hands of only a few. In one article, for example, she noted that nothing the defendants could say would "bridge the abyss of guilt and despair into which the German people have been thrown." 72 On the surface, her work acknowledged German responsibility, but the underlying message was that only a small circle had been responsible for leading Germany into that abyss.

Kardorff was eager to reach a readership outside of Germany with her message about German suffering and about the bravery of those who had participated in the July 20 assassination plot. ${ }^{73}$ In the early postwar years, she received foreign newspapers from friends and associates abroad, and was well aware of international opinion about her country. Like Friedrich, she turned to her transatlantic contacts in an effort to influence foreign views of Germany. During or shortly after the Berlin Blockade, which lasted from June 1948 to May 1949, Kardorff forwarded an article series she had written about the living conditions of West Berliners to Hans Wolfgang Schwerin, a Jewish-German émigré living in New York: "I would be pleased if you happen to know of a German[-language] newspaper over there that would be interested." She stressed that no payment would be necessary as long as the publication of the articles "did anything to encourage understanding for Berliners." 74

Although a prominent journalist, Kardorff was best known for her book, which was referred to and promoted as a diary: Berliner Aufzeichnungen aus den Jahren 1942 bis 1945. It was based on her wartime notes, as well as on postwar correspondence and feedback from friends and colleagues in Germany and abroad. ${ }^{75}$ Just like Friedrich, Kardorff explicitly stated that one of her goals in Berliner Aufzeichnungen was to solicit more understanding for Germany as a way in which to help it recover its reputation. She also felt it important to offer a narrative of Germany's wartime experience from a woman's perspective. ${ }^{76}$ Kardorff hoped to publish her manuscript abroad first, and, to that end, she initiated communication with her contacts in Switzerland, Great Britain, and the United States. In May 1946, she sent a rough draft to a contact in England for feedback, noting that, "most of all, I would like it to be published abroad in order to awaken more understanding for our disastrous fate."77 In 1947, Kardorff wrote that the purpose of her book was to "make something of the German situation clear to the idiotic Ausland, which does not grasp anything about it."78

The book was not published abroad or in Germany until the early 1960s. Several factors contributed to this delay. First, in contrast to Friedrich, Kardorff was reluctant to publish in Germany right after the war because she feared a negative reaction to her account of the July 20 plotters: after the war, a considerable segment of the German population still viewed the attempted assassination as treason. She also worried that the book's focus on

${ }^{71}$ IfZ, ED348/31, letter from Schöningh to Kardorff, April 6, 1946.

${ }^{72}$ IfZ ED348/520, Kardorff, "Schluss-Stimmung in Nürnberg," Stuttgarter Zeitung, n.d.

${ }^{73}$ IfZ ED348/6, letter from Kardorff to Kläre, Aug. 5, 1946.

${ }^{74}$ IfZ ED348/6, letter from Kardorff to Hans Wolfgang Schwerin, Nov. 12, 1948.

${ }^{75}$ See the foreword to Ursula von Kardorff, Diary of a Nightmare: Berlin 1942-1945, trans. Ewan Butler (New York: The John Day Company, 1966).

${ }^{76}$ IfZ ED348/6, letter from Kardorff to Charlotte von der Schulenburg, Aug. 20, 1947.

${ }^{77}$ IfZ ED348/6, letter from Kardorff to Guy Wint, May 1946.

${ }^{78}$ IfZ ED348/6, letter from Kardorff to Charlotte von der Schulenburg, Aug. 20, 1947. 
the German aristocracy "would not please the masses."79 Indeed, when Kardorff sent the manuscript to a German publishing house for feedback in 1948, the publisher encouraged her to continue to work on it, but stated that, in its present state, he could not envision much interest beyond her "narrow circle" of friends and associates. ${ }^{80}$

Kardorff's aristocratic lineage and the nature of the manuscript also hampered her chances of publishing abroad. One US reviewer expressed concern about Kardorff's limited experience of the war, given that she was a privileged aristocrat and had not known the travails of those in working-class districts. ${ }^{81}$ In addition, again in contrast to Friedrich, Kardorff was critical of US treatment of, and lack of understanding for, Germans. In her manuscript, she described the US forces as "a little simple-minded" and criticized both US denazification and reeducation efforts. ${ }^{82}$ "The Allies no longer threaten to bomb us," reads one diary entry from June 5 , 1945, "but now they talk to us like a governess. One has the feeling that one is sitting in a classroom and being continually rapped over the knuckles ... They talk about educating us in the ways of democracy, and, at the same time, try to peer into everybody's private affairs." 83

Kardorff also presented a more problematic figure than Friedrich did because of her nationalism and because of some of her articles that had appeared during the Third Reich. In fact, she was shut out of the Nuremberg trial proceedings for a short time by a US press officer because he had found her article on Albert Speer to be too nationalistic. ${ }^{84}$ Given that a primary goal of the US occupation force was to prevent the resurgence of German nationalism, American press authorities were extremely cautious about material that contained even a trace of such discourse. This vigilance was especially true with regard to press coverage of the trials, which the German population read closely. But since it had been American press authorities who had cleared Kardoff to cover the trials in the first place, she was soon allowed to return. ${ }^{85}$

Kardorff was also anxious about the quality of her manuscript, which was why she continued to massage it until it eventually appeared. Throughout the 1940s and 1950s, she sent it to several friends and colleagues in Germany and abroad for feedback. In numerous letters, she described to them her lack of confidence and her ongoing struggle with the book. In August 1947, for example, Kardorff wrote to a friend that she was "about to rewrite it for the second time ... Teddy [an acquaintance] read a part of the beginning and then encouraged me very much — not only he, also others. I am far too critical to be able to judge [it] at all ... But since wise men claim that I can do some good with it, I continue to work." 86 Berliner

${ }^{79}$ IfZ ED348/6, letter from Kardorff to Hans Wolfgang Schwerin, April 12, 1948.

${ }^{80}$ IfZ ED348/7, letter from Deutscher Verlag, Nov. 19, 1948.

${ }^{81}$ See Ursula von Kardorff's report on Berliner Aufzeichnungen in IfZ ED348/7.

${ }^{82}$ Kardorff, Diary of a Nightmare, 228.

${ }^{83}$ Ibid., 223-24.

${ }^{84}$ IfZ ED348/5, letter from Kardorff to Peter Boyle, Sept. 29, 1946; IfZ ED348/13, Ursula von Kardorff, “Tagebuch: Auszüge aus Nürnberg," July 8, 1946. Also see Ursula von Kardorff, "Speer-ein Mann mit Verantwortung," Wiesbadener Kurier, June 25, 1946.

${ }^{85}$ IfZ ED348/1, report from the Office of Military Government for Bavaria, Press Control Section, May $10,1946$.

${ }^{86}$ IfZ ED348/6, letter from Kardorff to Charlotte von der Schulenburg, Aug. 20, 1947. In 1948, she thanked Hans Wolfgang Schwerin for his positive feedback on the manuscript; in May 1957, former party member and author Erhardt Kästner wrote to thank Kardorff for sending him an excerpt from her book, and to assure her of its merit. See IfZ ED348/6, letter from Kardorff to Schwerin, April 12, 1948; ED348/5, letter from Kästner to Kardorff, May 5, 1957. 
Aufzeichnungen was first published in Germany in 1962, and then in the United States in 1966 as Diary of a Nightmare: Berlin 1942-1945. It received rave reviews in both countries. The book was republished in German in 1976 and again in 1992, shortly after German unification.

Berliner Aufzeichnungen combined the genres of literary work, diary, and memoir, with Kardorff's wartime notes providing a strong foundation for her book. Yet, it was only later that she added some important scenarios and viewpoints that reviewers praised in particular. In the first edition, she included "flashbacks" that expressed her hatred for the Nazis, as well as references to Jewish transports. Though her original entries contained a hint of disdain for Nazism, she wrote most of the passages critical of the Nazis after the war; no similar entries exist in the originals. ${ }^{87}$ She made other alterations as well, such as replacing all references to the "Führer" with "Hitler," in order to make the manuscript more acceptable to an audience outside Germany and to disassociate herself further from Nazism. Some of the revisions may have come at the request of her publisher, but the nature of Kardorff's correspondence about her draft manuscript suggests that she was very aware of what would (not) appeal to an international audience; she understood as well that one's anti-Nazi credentials could be used as a postwar negotiating tool to achieve legitimacy or receive favors. According to Kardorff, "one now has to make a kind of trade in these things ... and thereby gain advantages"-

Besides a desire to improve Germany's postwar reputation, Kardorff also had personal reasons for publishing her version of life under the Nazi regime: to secure her own postwar reputation. This explains why she highlighted her professional focus on culture, everyday life, and women's topics during the Third Reich. This was meant to demonstrate that she had avoided political discussion and had therefore not been complicit with the dissemination of Nazi propaganda. In an entry dated February 1945, but which was added at some point after the war, Kardorff wrote, for example: "So this is the end of six years' work. I hope that during those years I never sold out to the Promi [Propaganda Ministry] and that I never wrote anything really opposed to my convictions. Anyhow, I had the good fortune to be working in features, which saved me from having to do a lot of unpleasant things." 89 She presented not only herself as a journalist uncompromised by Nazism, but also her colleagues and the newspaper for which she worked in the same manner, emphasizing that some papers had been able to provide serious news. She described the Deutsche Allgemeine Zeitung, for instance, as a newspaper read by Germans but not Nazis. ${ }^{90}$ Kardorff dated this passage May 12, 1943; in fact, she only added it after the war.

Her treatment of former SS member Hans Schwarz van Berk demonstrates such efforts to rehabilitate the reputation of colleagues closely tied to the regime-and, by extension, of the German press more generally. In 1962, she received a letter from Joachim Friedrich Goldmann asking about the wartime record of Schwarz van Berk, who had been a

\footnotetext{
${ }^{87}$ Barbara Szerfozo, "Warring Narratives: The Diaries and Memoirs of Lore Walb, Ursula von Kardorff, and Margret Boveri" (PhD diss., Georgetown University, 2002), 155. Kardorff may have been able to write more openly in her diary after the war, but she also left out important biographical facts in Berliner Aufzeichnungen, such as her work for Der Angriff and her brother Klaus's membership in the SA.

${ }^{88}$ IfZ $348 / 6$, letter from Kardorff to Guy Wint, Nov. 13, n.d.

${ }^{89}$ Kardorff, Diary of a Nightmare, 193-94. In the postwar years, a number of women journalists claimed that their focus on soft news meant that they had not been compromised by Nazism.

${ }^{90}$ Ibid., 46.
} 
close colleague of Joseph Goebbels, as well as the editor of the party paper, Der Angriff, at the time Kardorff joined as a volunteer. The Nazis' "most prominent journalist," Goldmann wrote, was now working as an advertising consultant for a group of manufacturers, and a Jewish member of the group was seeking evidence against Schwarz van Berk's appointment. After learning that Kardorff had featured Schwarz van Berk in her recently published Berliner Auzeichnungen, Goldmann hoped that she would testify about his "inglorious past." 91

"I don't think I have ever answered a letter so quickly," Kardorff responded. "He [Schwarz van Berk] was in the Waffen SS and also a journalist for [the newspaper] Das Reich. He was a Nazi, but one of the most upstanding I knew." 92 Kardorff thus attested to Schwarz van Berk's decency, noting that she and others had been open with him about their anti-Nazi views, and emphasizing further that he had not tried to return to journalism and that he was no longer engaged in politics. "Not because of a bad conscience," Kardorff stressed, "but rather because, I believe, he had already seen and realized how gruesome everything was." $" 93$ Kardorff did not address details about Schwarz van Berk's wartime activities, including the fact that, while serving on the Eastern Front and witnessing the German atrocities perpetrated there, he had written virulent articles describing the "Russians" in dehumanizing terms. She also failed to mention that he had remained a committed Nazi to the bitter end, and that he had encouraged Germans to continue fighting to avoid occupation by a supposedly inferior race. ${ }^{94}$

In the heated exchange that followed, Goldmann expressed profound disappointment that Kardorff had defended Schwarz van Berk. "As a Jew," he wrote, "I refuse to engage in a discussion with you about which members of the SS were less murderous." 95 Kardorff's defence of her former colleague as a "good" Nazi was similar to Friedrich's claims of having belonged to a professional circle in which most journalists, even those who had belonged to the party, could speak freely with each other. In this way, both women presented the press, as well as their colleagues and friends, as tolerant of those who had been openly disdainful of Nazism.

If Kardorff sought to distance herself and other journalists from the Nazi regime in Berliner Aufzeichnungen, she also hoped to elicit sympathy for the German people. To that end, she described what she viewed as wartime and postwar injustices against the Germans, first by the Nazi regime and then by the Allies. She wrote about the reach of the Gestapo, the bombings, the mass rapes committed by the Red Army, the nature of the Allied occupation, as well as about what she considered to be Allied hypocrisy: "Dr. Meier said that when the war was over, we would be horribly punished and that the Allies would resort to measures that would affect every one of us ... Of course we do bear a dreadful weight of guilt, but so do the others - for instance, the British and Americans, who made it so difficult for the Jews who were trying to escape from Germany to enter their countries. They have no right to sit in judgement on us." 96 Although critical of the Western Allies, Kardorff saved her harshest criticism for the Soviets, referring to them in such derogatory terms as "the

\footnotetext{
${ }^{91}$ IfZ ED348/9, letter from Goldmann, Dec. 12, 1962.

${ }^{92}$ IfZ ED348/9, letter from Kardorff to Goldmann, Dec. 13, 1962.

${ }^{93}$ Ibid.

${ }^{94}$ Frei and Schmitz, Journalismus im Dritten Reich, 169.

${ }^{95}$ IfZ ED348/9, letter from Goldmann to Kardorff, Dec. 17, 1962.

${ }^{96}$ Kardorff, Diary of a Nightmare, 91.
} 
red pest" and "red flood." 97 Kardorff loathed the Russians, both during and after the Third Reich, and felt that communism was the same as, if not worse than, Nazism. The Red Army's seizure of the Kardorff's two estates in the East only added to her hatred. So, too, did the fate of her family: when the Soviets arrived at the Kardorff estate of Böhlendorf in May 1945, three of her relatives committed suicide. ${ }^{98}$

Yet, Kardorff also acknowledged German crimes, though in a more tepid manner than Friedrich did. She drew particular attention to the persecution and murder of European Jews, and her diary indicates the anguish and guilt she felt at the time as a German. Her frequent comparisons between wartime Jewish experiences and postwar non-Jewish ones nevertheless suggested that Germans had suffered from the war just as much as the Jews had. In one case, Kardorff described a conversation with US military personnel in July 1945 and wrote that Americans seemed naive: "When you are with them you suddenly feel burdened with the weight of centuries, old as the hills and complicated-a feeling which, apart from ourselves, perhaps only the Jews experience. What a similarity there is between the Germans and the Jews." 99

Kardorff's thoughts on injustice were clearly related to her views on class and to her experiences as a member of the Prussian nobility. She frequently complained that the occupying powers hated the Junkers, and, once again, compared their postwar situation with that of German Jews during the Third Reich. When completing an American questionnaire in July 1945, Kardorff was scornful of the questions: "Among other things they wanted to know ... whether our forebears had ever had any titles of nobility ... In the old days, a Jewish grandmother was the thing not to have had, but now the same applies to an aristocratic one." ${ }^{100}$ Kardorff had written about the questionnaire in her original diary notes, but added the sentence about "a Jewish grandmother" specifically for the book — an addition that indicates her desire to underscore the notion of German victimhood by comparing non-Jewish Germans with the actual victims of the Third Reich and of the war that Hitler had unleashed, namely, German and other European Jews.

There was a considerable gap between the time when Kardorff began to prepare her manuscript for publication and its eventual appearance. The reception of her work nevertheless demonstrates how a woman journalist's words reflected and informed several discursive trends about the Nazi past that developed in the immediate postwar years and in the 1960s. Berliner Aufzeichungen was published first in Germany in 1962-the same year that Friedrich's second book, Schauplatz Berlin (1945-1948), appeared-and it was also in negotiations to be published in the United States. ${ }^{101}$ After initial discussion during the Nuremberg trials, the German political, academic, and public spheres were relatively silent during the late 1940s and 1950s about German crimes against Jews under National Socialism. The Federal Republic did take some early steps to redress Third Reich atrocities, such as the 1952

\footnotetext{
${ }^{97}$ Ibid., 247.

${ }^{98}$ Kardorff, Berliner Aufzeichnungen, 361.

${ }^{99}$ Kardorff, Diary of a Nightmare, 228.

${ }^{100}$ Ibid., 229-30. For German views on Allied questionnaires and the experience of denazification, see, e.g., Ernst von Salomon, Der Fragebogen (Hamburg: Rowohlt, 1951).

${ }^{101}$ IfZ ED348/9, letter from Kardorff to von Garlowitz, Aug. 23, 1962.
} 
Luxembourg agreement, which provided restitution to Israel. Yet, any media discussion about the war and its aftermath focused largely on the German experience. ${ }^{102}$

This was a time when, in the words of Raul Hilberg, the "destruction of the European Jews ha[d] not yet been absorbed as a historical event." 103 It was not until the late 1950s and early 1960s that West Germany began slowly to confront its violent past. National and international events played a role in this process. The German Central Office for the Investigation of National Socialist crimes was established in Ludwigsburg in 1958, and the West German Einsatzgruppen trial took place in Ulm that same year. ${ }^{104}$ The 1961 Eichmann trial attracted global media interest and sparked more discussion about the Holocaust in the United States and Germany. The Auschwitz trials that took place in Frankfurt between 1963 and 1965 also marked a significant change in the German perspective on the war. Whereas the German population largely viewed the Nuremberg trials as a victor's justice, there was no such concern over the Frankfurt process because the German justice system judged the defendants. ${ }^{105}$

Whereas these events increased awareness of the crimes that had been committed against European Jews, the building of the Berlin Wall in August 1961 heightened the Cold War and reinforced the view of West Germans as victims of the Soviets, also in the eyes of many Americans. The publication of Kardorff's writing in the early 1960s and the reception of her book needs to be situated in this context of renewed discussion about German victimization, as well as an emerging focus on the Holocaust. Berliner Aufzeichnungen spoke to both German victimization and, though less prominently, German crimes against European Jews. At the same time, Kardorff's criticisms of the Soviet Union and her fears of communist aggression jibed with contemporary US and West German opinion. Her book also appeared at the same time as other autobiographical works focusing on the aristocracy's wartime experiences, including their involvement in the July 20 assassination attempt and the loss of the East to the Soviets. Journalist Marion von Dönhoff's Namen, die keiner mehr nennt was published in 1962, for instance. ${ }^{106}$

Widely reviewed at the time, Kardorff's book, like Friedrich's, found a receptive audience in Germany and the United States. Her account of the Nazi period and the war years was lauded for its alleged honesty and candor. Reviewers emphasized the fact that Kardorff was a female journalist, implying that this made her take on Germany's wartime experience particularly credible. Berliner Aufzeichnungen was on the bestseller list in Germany for several

\footnotetext{
${ }^{102}$ See Moeller, War Stories.

${ }^{103}$ As quoted in Christopher R. Browning, "Spanning a Career: Three Editions of Raul Hilberg's Destruction of the European Jews," in Lessons and Legacies, Vol. VIII, ed. Doris Bergen (Evanston, IL: Northwestern University Press, 2008), 191.

${ }^{104}$ See Patrick Tobin, "No Time for 'Old Fighters': Postwar West Germany and the Origins of the 1958 Ulm Einsatzkommando Trial," Central European History 44, no. 4 (2011): 684-710.

${ }^{105}$ See Rebecca Wittmann, Beyond Justice: The Auschwitz Trial (Cambridge, MA: Harvard University Press, 2005); Devin O. Pendas, The Frankfurt Auschwitz Trial, 1963-1965: Genocide, History, and the Limits of the Law (New York: Cambridge University Press, 2006).

${ }^{106}$ Marion von Dönhoff was a Junker from East Prussia who participated indirectly in the July 20 plot. She fled her home in January 1945 ahead of the Red Army. After the war, she became one of Germany's most prominent female journalists. See Marion von Dönhoff, Namen, die keiner mehr nennt: Ostpreussen-Menschen und Geschichte (Düsseldorf: Diederichs, 1962). See also Volker Berghahn, Journalists between Hitler and Adenauer: From Inner Emigration to the Moral Reconstruction of West Germany (Princeton, NJ: Princeton University Press, 2018).
} 
weeks in 1962 and, like Friedrich's text, ran in the popular series "Chronical of Our Most Difficult Days."107 The Neue Zürcher Zeitung praised Kardorff as an "unsuspicious witness," indeed because of her very profession. ${ }^{108}$ She also received positive reviews in the Frankfurter Allgemeine Zeitung and Der Spiegel. Private letters to Kardorff were mostly enthusiastic. One man who understood the public relations value of the book wrote that someone had shown finally that one could not only paint the behavior of Germans during those difficult years in black and white; he hoped, moreover, that the book would be widely published, particularly overseas. ${ }^{109}$ A German woman writing from Sweden similarly declared, "I am so pleased that you write [about] it, because the pressure of the years 1934-1945 still lies on [my children]. So much so that, for example, my two oldest children have suffered for years for being related to Germans, [a country] that invented the gas chambers." ${ }^{110}$ After having read the final manuscript, a friend of Kardorff's commented that "all these years we were more ashamed than we had reason [to be]; the shame and disgrace has covered up everything else." 111

The reception in the United States was equally favorable, both to Kardorff's selfpresentation and to the image she created of Germany. One reviewer described Kardorff as "a journalist who [had] kept her sympathies in check [during the Third Reich] by not taking on any political assignments." 112 Another review spoke to her status as a journalist and a woman, praising Kardorff for having helped the average American reader gain new insights into the German war experience. ${ }^{113}$ The New Yorker wrote that, as a journalist for a respected Berlin daily, Kardorff was "a well-placed observer" of events; it described her book as "instructive," and quoted phrases that highlighted both German suffering under the Nazis and the supposed integrity of the German population during that period. ${ }^{114}$ The American author, critic, and editor Bernardine Kielty Scherman remarked: "This is the first expression of anti-Nazism from a German in which this reader has felt trust ... We on the outside have had an accumulation of Jewish atrocity stories, but here we see the growing realization of those horrors among decent Germans." 115 The Wall Street Journal expressed similar sentiments, applauding Kardorff's strongly anti-Nazi beliefs, and noting that she "explodes with indignation at the maltreatment of the Jews." 116 In light of such positive reviews, the American Library Association suggested that small US libraries buy Kardorff's book. ${ }^{117}$

${ }^{107}$ IfZ ED348/9, letter from Max Tau, Aug. 9, 1962.

${ }^{108}$ IfZ ED348/31, Josef Halperin, "Berliner Aufzeichnungen, 1942-1945," Neue Zürcher Zeitung, Sept. 12, 1962.

${ }^{109}$ IfZ ED348/9, Karl Bergmann, letter to Die Welt, Sept. 4, 1962.

${ }^{110}$ IfZ ED348/9, letter from von Rutkowski to Kardorff, Feb. 18, 1962.

${ }^{111}$ IfZ, ED348/5, anon., letter to Kardorff, Nov. 12, 1961.

${ }^{112}$ Kirkus Review, April 20, 1966.

${ }^{113}$ Saturday Review, May 21, 1966.

${ }^{114}$ IfZ ED348/31, "Diary of a Nightmare: Berlin, 1942-1945," The New Yorker, n.d.

${ }^{115}$ IfZ ED348/31, Bernardine Kielty, "Diary of a Nightmare: Berlin, 1942-1945," Book of the Month Club News, Sept. 1, 1966.

${ }^{116}$ IfZ ED348/31, “Diary of a Nightmare,” Wall Street Journal, June 13, 1966.

117 “Diary of a Nightmare by Ursula von Kardorff, ”Booklist 63, no. 91 (1966). 


\section{Conclusion}

This article has demonstrated how journalists Ruth-Andreas Friedrich and Ursula von Kardorff used their autobiographical writing as a means to influence international opinion about Germany, particularly in the United States, and thereby help to rehabilitate the reputation of their country. Both women strove to lessen the taint of Nazism by acknowledging German responsibility for the war. At the same time, they offered a narrative that distorted the degree of assistance ordinary Germans provided to those who had been persecuted, downplayed the population's support of Nazism, and highlighted Germany's own suffering during the Third Reich. In so doing, they contributed to, legitimized, and reflected West Germany's own self-perception as a victim of Nazism and the postwar occupation. Moreover, these female journalists carved out a place for themselves among the male-dominated American and West German elites who endeavored to rebuild the relationship between their two countries using "soft-power" means.

The women's gender and profession were instrumental in the influence they exerted. As women, they had not occupied decision-making or leadership positions in the Nazi media landscape. Though prominent, they were seen to represent all women journalists and ordinary Germans. Displaying journalistic skills, both women strove for some semblance of objectivity in their writing, not least through their acknowledgment of prewar and wartime victimization of the Jews. This approach, along with their profession, lent their words credence and a sense of balance, which only strengthened the credibility of their narratives in both Germany and the United States. That was why German and US reviewers and readers alike accepted their writing as having "all the ring of truth." 118 The fact that both books have been repeatedly republished, and that they continue to be used as sources in both scholarly studies and more popular histories, attests to their ongoing popularity and preceived credibility. ${ }^{119}$

Scholars have identified the narrative of German victimization and the country's focus on its own suffering that emerged in the years and decades following the war, and they have also analyzed how this narrative became an important part of West Germany's national identity. ${ }^{120}$ At the same time, however, they have not taken into account the way in which the writing of women journalists significantly contributed to that discourse. As this article has argued, the autobiographical writing of journalists such as Friedrich and Kardorff played an important part in refashioning the memory of Nazism and the war into a narrative that influenced both its relationship with its former enemies and the process of Vergangenheitsbewältigung - thus playing a major role in the domestic and international rehabilitation of West Germany after 1945.

UNIVERSITY OF MONTREAL

\footnotetext{
${ }^{118}$ Rothfels, German Opposition to Hitler, 33.

${ }^{119}$ In addition to the works already cited, see, e.g., Giles MacDonogh, After the Reich: The Brutal History of the Allied Occupation (New York: Basic Books, 2007); Antony Beevor, The Fall of Berlin, 1945 (New York: Penguin, 2003); Earl R. Beck, Under the Bombs: The German Homefront 1942-1945 (Lexington: University Press of Kentucky, 1986); Alexandra Garbarini, Numbered Days: Diaries and the Holocaust (New Haven, CT: Yale University Press, 2006).

${ }^{120}$ See Moeller, War Stories; Heineman, "The Hour of the Woman."
} 